\title{
Nilai-Nilai Pendidikan dalam Hadits Ibadah Aqiqah
}

\author{
M. KHOIR AL-KUSYAIRI \\ Sekolah Tinggi Ekonomi Islam Iqra Annisa \\ Jl. Riau Ujung No. 47 Kota Pekanbaru e-mail: alkhusyairi@gmail.com. HP. 085271764720
}

\begin{abstract}
Abstrak: Ibadah aqiqah merupakan ibadah yang dilakukan oleh orang tua setelah anaknya lahir kedunia. Dalam islam, anjuran ibadah aqiqah termuat dalam hadits dari Rasulullah yang kemudian diriwayatkan oleh para sanad dan perawinya. Terdapat beberapa perbedaan menurut para alim ulama terkait tentang ibadah aqiqah ini. Namun demikian, para alim ulama tersebut menyetujui bahwa dalam pelaksanaan ibadah aqiqah ini terkandung nilai-nilai pendidikan didalamnya. Tulisan ini mengupas tentang penjelasan hadits yang berhubungan dengan ibadah aqiqah dan nilai-nilai pendidikan yang terkandung didalamnya. Tulisan ini juga memaparkan kedudukan hadits yang meriwayatkannya.
\end{abstract}

Kata kunci: Hadits, nilai-nilai pendidikan, aqiqah.

\section{PENDAHULUAN}

Islam adalah agama yang paling sempurna dan agama yang mencakup seluruh aspek kehidupan. Dalam menjalani kehidupan seorang muslim diharuskan berpegang teguh kepada dua hal yang disebut Nabi dalam sebuah hadits yaitu al-Qur'an dan al-Hadits. Di dalam kedua sumber hukum Islam tersebut telah tercantum semua tentang hukum-hukum yang mengatur kehidupan.

Hadits merupakan Perkataan, Perbuatan dan Taqrir Nabi Muhammad SAW yang dijadikan sebagai sumber hukum Islam yang kedua. Namun ia tidak hanya membahas tentang hukum dan ibadah saja, akan tetapi pembahasannya lebih luas dari itu, misalnya membicarakan tentang aqidah/keyakinan, budaya, sosial kemasyarakatan, adab, akhlak dan lain sebagainya.

Salah satu contoh Sunnah atau Hadits yang membicarakan masalah sosial kemasyarakatan tersebut adalah hadits tentang aqiqah. Melalui Ibadah ini, Nabi Muhammad SAW menyampaikan pesan-pesan dan nilainilai yang mesti dilaksanakan ummatnya. Dalam tulisan ini pemakalah mendeskripsikan tentang syari'at aqiqah dalam agama Islam, selanjutnya, mentakhrij dan menganalisa hadits tersebut, dan pada kesimpulannya penulis mengemukakan tentang hikmah syariat aqiqah dan nilai-nilai pendidikan apa saja yang terdapat dalam Ibadah Aqiqah. 


\section{HADIST TENTANG ANJURAN IBADAH AQIQAH}

Berdasarkan informasi Mu'jam al-Mufahras li al-fazh al Hadits anNabawi, dengan menggunakan kata kunci رهينة maka diperoleh informasi bahwa hadits tersebut diriwayatkan oleh tiga orang mukharrij, yaitu Abu daud, Addarimi dan Ahmad bin Hanbal (Wensink, 1943: 313). Dalam kajian ini penulis memilih satu diantara tiga kitab yang disebutkan tersebut yaitu hadits yang terdapat dalam kitab Sunan Abi Daud (Daud, tt: 106). Adapun Teks haditsnya sebagai berikut:

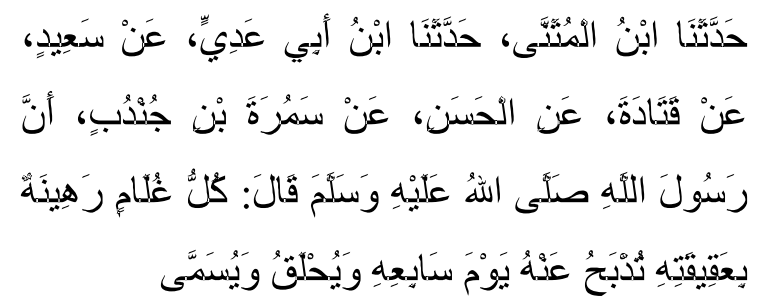

\section{Makna Mufradat}

Kata " غلام " berarti seorang anak yang baru lahir, sampai ia menjadi dewasa (Manzur, tt: 3289). Sedangkan "عقيقة" (Aqiqah) berasal dari kata 'Aqqa yang berarti mencukur. Atau menyembelihkan kambing. Makna Hadits "Setiap anak tergadai dengan aqiqahnya", maksudnya adalah bahwa ayahnya terhalangi mendapat syafa'at dari anaknya yang belum diaqiqahkan. Sedangkan Makna Asli aqiqah adalah rambut yang ada di kepala bayi yang baru lahir (Manzur, tt: 3044).

Kata "رهينة" (Rahana) : menetapnya sesuatu, tertahan haknya atau bukan haknya. Akan tetapi dalam hadits ini maksud tertahan haknya adalah tergadai haknya sebelum diaqiqahkan (Ahmad, tt: 452). Dalam Kamus Lisan al'Arab, kata rahana berarti menggadaikan sesuatu, tergadainya karena kotoran di rambut si anak (Manzur, tt: 1757), oleh karena itu untuk membebaskan anak dari kotoran maka di cukur rambutnya sebagaimana maksud hadits dalam Shahih Bukhari :

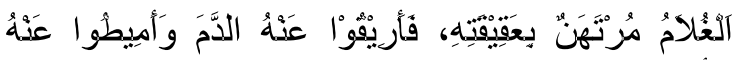
الأذى

Artinya: "Seorang bayi tergadai dengan aqiqahnya, maka alirkan darah (sembelihan aqiqah) untuknya dan singkirkan kotoran (cukurlah rambut) darinya."

Kata "يحلق" "يقل yang bermakna : Mencukur rambut. Dalam sebuah hadits, disebutkan dalam kitab Shahih Bukhari, Rasulullah SAW berdo'a:

$$
\text { اللهم اغفر للمحلقين }
$$

Artinya: "Ya Allah ampunilah orangorang yang mencukur."

Maksud hadits ini adalah orang yang mencukur rambut dalam Ibadah Haji dan Umrah (Manzur, tt: 966). Jadi makna yuhlaqu adalah dicukur rambutnya, karena fi'il (kata kerja) nya dalam bentuk pasif (Fi'il Majhul).

\section{Makna Ijmali Hadits}

Hadits ini menjelaskan tentang pentingnya syari'at Aqiqah, ia merupakan suatu sembelihan yang dilaksanakan berkaitan dengan lahirnya seseorang, baik laki-laki ataupun perempuan sesuai dengan ketentuanketentuan syara'. Jika telah lahir seorang bayi laki-laki maupun perempuan maka orang tua bayi tersebut, disunnahkan mengaqiqahi anaknya dengan cara menyembelihkan dua ekor kambing untuk anak laki-laki dan satu ekor kambing untuk anak perempuan. Maka makna aqiqah secara umum adalah menyembelih kambing untuk anak pada hari ketujuh dari hari kelahirannya. 
Aqiqah merupakan salah satu bentuk kasih sayang orang tua terhadap anaknya dan syari'at aqiqah ini juga merupakan bentuk taqarrub (pendekatan diri) kepada Allah sekaligus sebagai wujud rasa syukur atas karunia yang dianugerahkan Allah SWT. Disamping itu juga, Aqiqah sebagai sarana menampakkan rasa gembira dalam melaksanakan syari'at Islam sekaligus menampakkan syi'ar kebersamaan sesama kaum muslimin.

Jadi secara sederhana syari'at aqiqah dapat ditinjau dari dua aspek. Pertama adalah aspek vertikal sebagai bentuk syukur kepada Allah atas karunia yang diperoleh, dan yang Kedua adalah aspek horizontal dengan mengaktualisasikan rasa syukur tersebut melalui penyembelihan hewan yang dibagikan pada masyarakat sekitar.

\section{MATAN DAN SANAD HADITS TERKAIT ANJURAN IBADAH AQIQAH}

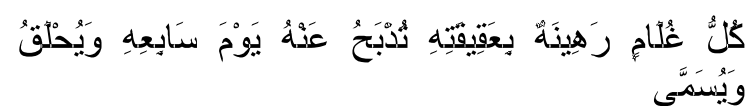

Setiap anak yang lahir tergadai dengan aqiqahnya, maka pada hari ketujuh disembelih hewan, dicukur rambutnya, dan diberi nama (Daud, tt: 106).

Adapun skema sanad Hadits ini sebagai berikut :

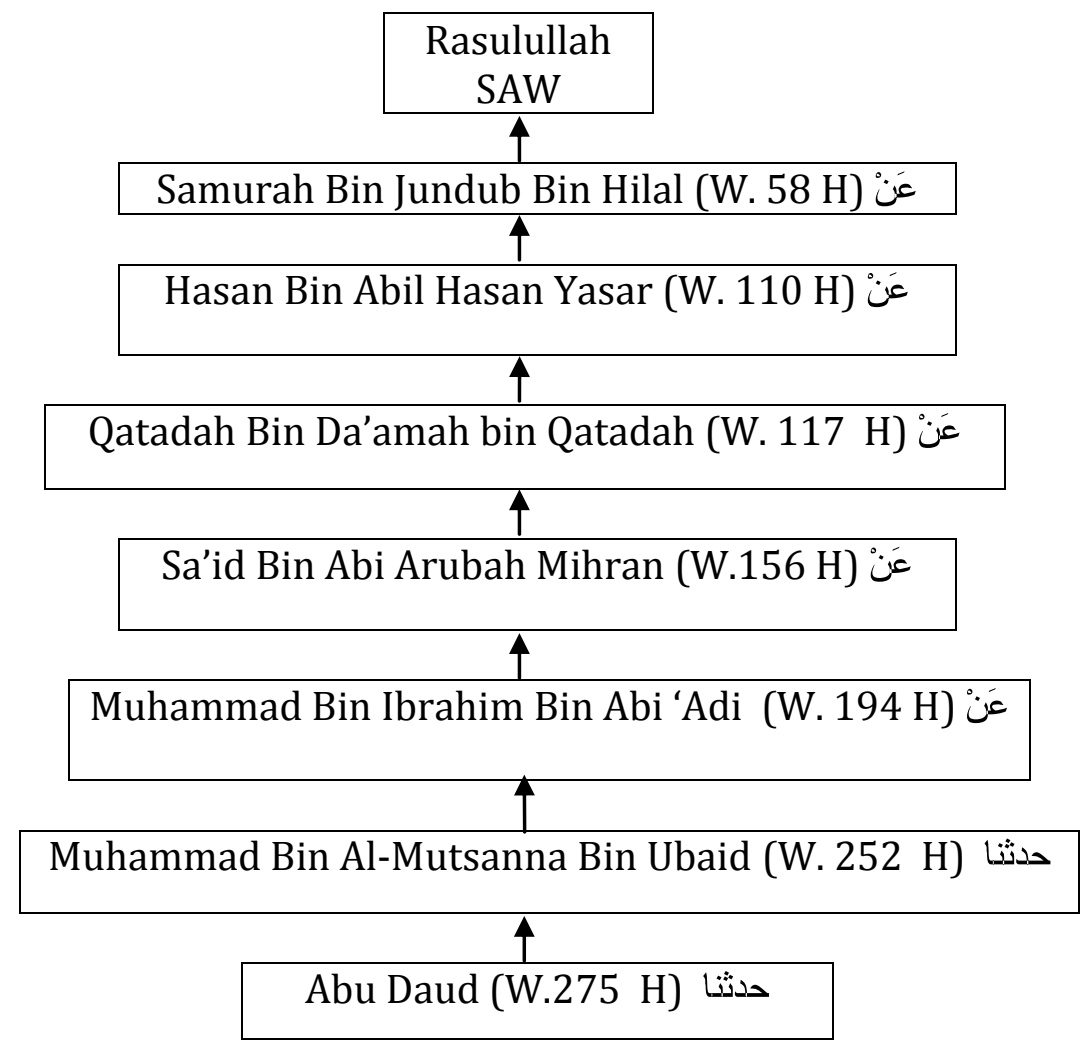

\section{Imam Abu Daud}

Abu Daud adalah Sulaiman bin alAsy`as bin Ishaq bin Bisyri bin Syaddad bin 'Amr bin Imran al-Azdi al-Sijistani. Beliau dilahirkan pada tahun $202 \mathrm{H} /$ 284M. Dan hidup pada masa dinasti
Abbasiyyah. Yang mana pada saat itu sedang diperlukannya seorang pengumpul hadits-hadits Nabi yang masih banyak belum terkumpul. Pada ssat itu juga banyak terdapat pemalsuan tentang hadits Nabi. 
Abu Daud merupakan seorang ulama hadits yang berjasa membuat kitab As-Sunan Abu Daud, sebagai karya klasik yang dijadikan pegangan para ulama hadits sesudahnya. Adapun dari segi metodologisnya, Abu Daud telah melakukan penyaringan sekitar 500.000 hadits atau sanad, yang kemudian dari hasil penyaringan ini dihasilkan 4.800 hadits hukum atau bisa dikatakan hanya mengambil kurang dari 1\% dari hadits yang dikumpulkan.

Dari sini terlihat bahwa Abu Daud ulama yang teliti. Hadist dari `Abdullah ibn Maslama al-Qanaby, Abul Walid ath Thayalisy, `Abu `Amar al Haudly, Ibrahim ibn Musa al-Farra', Abu Bakar ibn Abi Syaibah 'Utsman bin Abi Syaibah, Ahmad ibn Shalih, Ahmad ibn Hambal, Yahya ibn Ma`ien, Ishaq ibn Rahawaih, Abu Tsaur Qutaibah ibn Sa id, dll, adalah hadits yang diriwayatkan oleh Abu Daud. Selain dilihat dari hasil karyanya, beliau juga dipandang sebagai seorang ulama hadits yang memiliki tingkat hafalan dan pemahaman hadits cukup tinggi. Sekaligus memiliki berkepribadian wara dan taat beribadah dengan pemahaman agamanya yang kuat. Ia wafat di kota Basrah pada hari jum'at tanggal 16 bulan syawwal tahun 275 Hijriah, ketika beliau berumur 73 tahun atau pada tahun $900 \mathrm{M}$.

Berikut beberapa pengakuan dari para Ulama tentang Abu Daud: (a) Semua ulama mengakui bahwa Abu Daud, adalah salah seorang imam dunia, baik dalam bidang fiqh, hafalan dan ibadah. Beliau terhitung salah seorang ulama yang membela sunnah; (b) Pengakuan ulama tentang keahliannya di bidang hadits sangat beralasan untuk menempatkan Abu Daud sebagai Imam muhaddis (ahli hadits) yang besar dan terpercaya. Kesungguhannya dalam melacak hadits dapat dilihat dari perjalanannya menempuh jarak jauh dari Basrah ke al-Jazair, Khurasan, Syam, Hijaz, Mesir dan lain-lainnya, juga usahanya menggali hadits dari para Syaikh ; dan (c) Menurut penilaian Ibnu Mandah, Abu Daud termasuk tokoh hadits yang berhasil menyaring haditshadits sehingga ia dapat memisahkan antara hadits yang tsabit (tetap keabsahannya) dengan yang ma'lul (yang ada cacatnya) dan antara yang benar yang keliru, disamping Bukhari, Muslim dan an-Nasa`i (Usman, 1979: 4).

\section{Muhammad bin Al-Mutsannaa bin 'Ubaid}

Beliau adalah Muhammad bin Mutsanna bin 'Ubaid. Beliau dikenal sebagai Abu Musa al-Bashri pada zamannya.

Guru beliau adalah Abdullah bin Idris, Abu Muawiyah, Khalid din Warits, Yazid bin Zurai', Husainn bin Hasan Bisry, Mu'tamar, Hafs bin Giyas, Ishaq bin Yusuf, abu Nu'man al-Ajaly, Hamad bin Sahl, Muhammad bin Fadil, Husain bin Jurair, Ibnu Uyainah, Abdullah alTsaqafy, Abdullah bin Hamran, Abdul A'la, Muhammad bin Abdullah alAnshary, Ja'far, Muhammad bin Harun, makiy bin Ibrahim, dan ulama yang lainnya.

Sedangkan muridnya ialah Jama'ah, Abu ya'la ahmad bin ali bin al mutsanna, abu arubah al husain bin muhammad alharrani, serta yang lainnya.

Abdullah bin Ahmad bin hanbal mengatakan bahwa beliau adalah Tsiqah. Abu Saad al-Harawi di tanya oleh Az-Zahaly tentang beliau, dan Ia mengatakan bahwa (Muhammad bin alMutsanna) beliau itu Hujjah. Ibnu Hibban menuliskan namanya dalam kitab Ats-Tsiqaat. Disebut juga bahwa ia Tsiqah dan Tsabat. Beliau lahir pada tahun 167 Hijriyah, dan wafat pada 252 Hijriyah. 


\section{Muhammad bin Ibrahim bin Abi Adi}

Muhammad bin Ibrahim bin Abi Adi dikenal juga dengan nama Abu Amru al-Bashri. Guru-guru yang pernah mengajar Muhammad bin Ibrahim bin Abi Adi adalah Humaid at tawil, sulaiman at taimi, Daud bin abi hindi, Ibnu aun, auf al a'rabi, husain al mu'allim, said bin abi arubah, yunus bin ubaid, dan lain sebagainya.

Diantara murid-murid Muhammad bin Ibrahim bin Abi Adi yang terkenal adalah ahmad bin hanbal ahmad bin sinan al qattan, abu bisyr bakr bin khalaf, abu musa muhammad bin al mutsanna, dan lain sebagainya.

Menurut Abu Hatim dan An Nasai mengatakan bahwa Muhammad bin Ibrahim bin Abi Adi adalah tsiqah. Beliau wafat di bashrah pada tahun $194 \mathrm{H}$.

\section{Sa'id bin Abi Arubah}

Ia juga dikenal dengan Abu Nadhr al-Basri. Guru-gurunya adalah : Qatadah, Nadhr bin Anas, Hasan al-Basri, Abdullah bin Fairuz Addanaj, Ziyadah A'lam, Ali bin Hakam, Abi Nadhrah alAbdi dll.

Murid-muridnya: A'masy, Syu'bah Abdul a'la, Khalid bin Harits, Yazid bin Zurai', Abu Bahr al-Bakrawi, Muhammad bin Bisyr, Muhammad bin Abdullah alAnshari, dan lain sebagainya.

Penilaian ulama seperti Ibnu ma'in tentang beliau adalah bahwa ia adalah seorang yang tsiqah, demikian pula penilaian An-Nasai bahwa ia adalah seorang yang tsiqah. Berbeda dengan Abu Zur'ah ia menilai bahwa Sa'id bin Arubah adalah seorang yang tsiqah ma'mun. Sementara itu Abu Hatim menilai bahwa ia seorang yang tsiqah sebelum ikhtilath. Beliau wafat pada tahun $156 \mathrm{H}$.

\section{Qatadah bin Da'amah}

Beliau adalah Qatadah bin Da'amah bin Qatadah bin 'Azin bin 'Amr bin Rabi'ah bin 'Amr bin Harits bin Sadus.

Beliau meriwayatkan hadits dari guru beliau yaitu Anas bin Malik, Badil bin Maisarah, Basyar bin 'Aidz, Basyar bin Muhtafar, Bakr bin 'Abdullah, Salim bin 'Abdi Ja'ad, Said bin Abi Jardah,Abi Musa Al-'Asy'ary, serta yang lainnya. Sedangkan yang meriwayatkan hadits darinya atau murid-murid beliau adalah Aban bin Yazid al-'Athary, Ayub AlSakhyatany, Jarir bin Hazim, Hajaz bin Artoah, Sa'id bin abi Urwah, Syu'bah bin Hajaz, Syaiban bin 'Abdurrahman alNahwy, dan lainnya.

Para ulama seperti Yahya bin Ma'in, menyatakan bahwa ia Tsiqah. Dalam kitab Mizan, bahwa beliau adalah ulama yang Tsiqah, Hafidz, Tsabat, akan tetapi ia Mudallis. Menurut Yahya beliau lahir pada tahun ke 60 Hijriyah, Namun menurut Amr bin 'Aly, beliau lahir pada tahun 71 Hijriyah. Sedangkan tahun wafatnya adalah pada tahun $117 \mathrm{H}$.

\section{Al-Hasan bin abi al hasan yasar al Bashri}

Al-Hasan al-bashri adalah Maula Al-Anshari. Ibunya bernama Khairah, budak Ummu Salamah yang dimerdekakan, dikatakan Ibnu Sa'ad dalam kitab thabaqat Hasan adalah seorang alim yang luas dan tinggi ilmunya, terpercaya, seorang hamba yang ahli ibadah dan fasih bicaranya. Bapaknya bernama Pirauz (kemudian dikenal sebagai Abul Hasan), yang menjadi budak pada zaman pemerintahan Khalifah Umar bin AlKhattab. Dari kampungnya Pirauz kemudian dibawa ke Madinah sebagai seorang tawanan. Pirauz dan seorang perempuan dari kampungnya, diberikan kepada Ummu Salamah. Lalu Ummu 
Salamah memberikan mereka berdua kepada saudara terdekat beliau dan keduanya lantas menikah dengan tuan mereka dan dibebaskan.

Hasan Al-Basri dilahirkan di Madinah pada tahun 21 Hijriah (642 Masehi). Beliau pernah menyusu dengan Ummu Salamah, isteri Rasulullah S.A.W. Pada usia 14 tahun, Al-Hasan pindah ke kota Basrah, Irak, dan menetap di sana. Dari sinilah Al-Hasan mulai dikenal dengan sebutan Hasan Al-Bashri. Hasan kemudian dikategorikan sebagai seorang Tabi'in (generasi setelah sahabat). Hasan al-Basri juga pernah berguru kepada beberapa orang sahabat Rasulullah S.A.W. sehingga beliau muncul sebagai Ulama terkemuka dalam peradaban Islam.

Hasan Al Bashri berguru pada para sahabat Nabi, antara lain: Utsman bin Affan, Abdullah bin Abbas, Ali bin Abi Talib, Abu Musa Al-Asy'ari, Anas bin Malik, Jabir bin Abdullah and Abdullah bin Umar. Al-Hasan menjadi guru di Basrah, (Iraq) dan mendirikan madrasah di sana. Di antara para pengikutnya yang terkenal adalah Amr ibn Ubaid dan Wasil ibn Atha. Beliau salah seorang fuqaha yang berani berkata benar dan menyeru kepada kebenaran di hadapan para pembesar negeri dan seorang yang sukar diperoleh tolak bandingnya dalam soal ibadah. Beliau menerima hadits dari Abu Bakrah, Imran bin Husein, Jundub, Al Bajali, Muawiyah, Anas, Jabir dan meriwayatkan hadits dari beberapa sahabat diantaranya 'Ubay bin Ka'ab, Saad bin Ubadah, Umar bin Khattab walaupun tidak bertemu dengan mereka atau tidak mendengar langsung dari mereka. Dan kemudian hadits-haditsnya diriwayatkan oleh Jarir bin Abi Hazim, Humail At Thawil, Yazid bin Abi Maryam, Abu Al Asyhab, Sammak bin Harb, Atha bin Abi Al Saib, Hisyam bin Hasan dan lain-lain.
Hasan Al-Basri meninggal dunia di Basrah, Iraq, pada hari jum'at 5 Rajab 110 Hijrah (728 Masehi), pada umur 89 tahun. Hasan adalah pendukung kuat nilai tradisional dan cara hidup zuhud, kehidupan dunia hanyalah perjalanan untuk ke akhirat, dan kesenangan dinafikan untuk mengendalikan nafsu. Tetapi dia bukanlah seorang sufi. Khutbah-khutbah beliau dianggap sebagi contoh terbaik dan terawal sastra Arab.

\section{Samurah bin Jundub}

Beliau adalah Samurah bin Jundub bin Hilal bin Harij bin Murrah bin Hazn bin Amr bin Jabir bin Khasyin bin Luay bin Asham bin bin Syamakh bin Fazarah bin Dzabyan bin Baghidh bin Raits bin Ghathafan Al-Fizary, kunyahnya Abu Sa'id/Abu Abdurrahman/Abu Abdillah atau Abu Sulaiman, tinggal di kota Basrah.

Ketika kecil ia dibawa ibunya ke kota Madinah dan dibesarkan di sana setelah ayahnya meninggal. Kemudian ibunya menikah lagi dengan seorang dari Anshar yang bernama Muri bin Sinan bin Tsa'labah. Ia tinggal bersama ayah tirinya sampai masa remaja. Beliau tidak sempat menemui masa jahiliyah, dan bertemu dengan Nabi ketika remaja.

Beliau ini sangat jujur, tidak pernah bohong dan mencintai Islam, salah seorang pejabat kekhalifahan yang berasal dari Ansar. Beliau berdomisili dan meninggal di Basrah di masa pemerintahan Muawiyah, beliau ini sangat tegas dalam menghadapi kaum sparatis Khawarij.

Pada saat perang Uhud, saat itu Samurah Bin Jundub belum menginjak usia dewasa. Ia bersama beberapa anak lainnya yang mempunyai semangat juang tinggi untuk membela panji keislaman, dikeluarkan dari barisan pasukan perang Uhud oleh Nabi SAW 
karena belum cukup umur. Tetapi salah seorang di antaranya, Rafi bin Khadij, karena permintaan ayahnya dibolehkan oleh Nabi SAW ikut karena ia mempunyai keahlian memanah, dan menunjukkan kemampuannya di hadapan beliau.

Melihat dibolehkannya Rafi ikut bertempur, Samurah berkata kepada ayah tirinya, Murrah bin Sinan RA, "Wahai ayah, Rafi dibolehkan ikut berperang sementara saya tidak. Padahal saya lebih kuat daripada Rafi. Kalau diadu tanding, pasti saya dapat mengalahkan Rafi."

Melihat semangat yang begitu menggebu dari anaknya ini, Murrah menyampaikan hal ini pada Nabi SAW, beliaupun mengadakan adu kekuatan antara Rafi dan Samurah, dan ternyata Samurah memenangkannya, sehingga iapun dbolehkan ikut serta dalam pertempuran di Uhud itu. Ketika itu Samurah berusia 15 tahun, sama seperti Rafi. Samurah bin jundub (wafat $56 \mathrm{H}$ )

\section{Takhrij Hadis}

Hadis ini disebutkan dalam kitb Sunan Abi Daud, Sunan Ad-Darimi dan Musnad Ahmad Bin Hanbal, hadits ini dishahihkan oleh Al-Hakim dan disetujui oleh Adz-Dzahabi. Maka kesimpulannya adalah bahwa hadis ini adalah Hadits Shahih.

\section{Penilaian Sanad}

Adapun penilatian sanad pada hadits terkait aqiqah ini ialah: (a) Sanadnya tersambung sampai ke Nabi; dan (b) Semua rawinya tsiqah kecuali Sa'id (empat orang menilainya tsiqah, dua orang menilainya tsiqah namun mukhtalith di akhir umurnya), alHasan (dua orang mengatakan tsiqah, satu orang mengatakan tadlis).

\section{Penilaian Matan}

Tidak ada masalah dalam matannya. Dari hasil penelitian tersebut dapat disimpulkan bahwa hadits tersebut maqbul, karena meskipun ada sebagian rawi yang tidak tsiqah namun ketidak tsiqahannya tidak terlalu parah. Selain itu, hadits ini didukung oleh banyak jalur sanad yang lain.

\section{Penjelasan Tentang Fiqih Hadits Definisi Aqiqah}

'Aqiqah berasal dari kata 'aqqa (عَقَُ) yang mempunyai arti memotong. Ibnul-Qayyim menukil perkataan Abu 'Ubaid bahwasannya Al-Ashmaa'i dan lain-lain berkata :

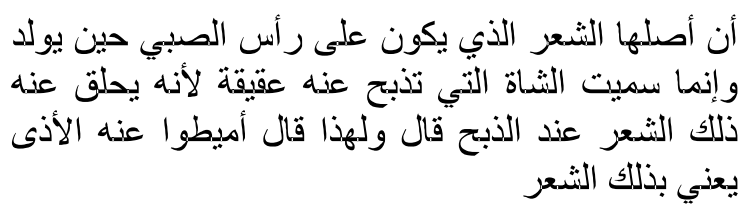

Artinya: "Pada asalnya makna 'aqiqah itu adalah rambut bawaan yang ada di kepala bayi ketika lahir. Hanya saja, istilah ini disebutkan untuk kambing yang disembelih ketika 'aqiqah karena rambut bayi dicukur ketika kambing tersebut disembelih. Oleh karena itu, disebutkan dalam hadits : "Bersihkanlah dia dari kotoran". Kotoran yang dimaksud adalah rambut bayi (yang dicukur ketika itu) (Al-Jauziyyah, 1403: 33-34).

Kata 'aqiqah adalah isim musytaq (pecahan) dari kata "al-'aqqu" yang berarti al-qath'u, yakni memotong/ terpotong. Menurut al-Azhariy dalam "al-Tahdzib" yang mengutip pernyataan Abu 'Ubaid, bahwa 'aqiqah pada mulanya berarti "rambut yang ada pada kepala seorang bayi ketika ia dilahirkan." Aqiqah juga berarti "kambing yang disembelih untuk anak yang baru dilahirkan." 


\section{Asbabul Wurud}

Dalam kitab-kitab asbabul wurud, memang secara spesifik tidak disebutkan kenapa Nabi bersabda mengenai 'Aqiqah. Akan tetapi jika ditinjau dari kronologis dan aspek sejarah, berkaitan dengan aqiqah ini, sebenarnya syari'at menyembelih dua ekor kambing jika anaknya laki-laki, dan seekor kambing jika anaknya perempuan, telah dikenal dan biasa dilakukan orang sejak zaman jahiliyah, namun dengan cara yang berbeda dengan yang dituntunkan oleh Nabi SAW bagi umat Islam.

Dalam Kitab Sunan Abi Daud, disebutkan bahwa Buraidah berkata: "Dahulu kami di masa jahiliyah apabila salah seorang diantara kami mempunyai anak, maka kami menyembelih kambing dan melumuri kepala bayi dengan darah kambing itu. Maka setelah Allah mendatangkan Islam, kami menyembelih kambing, mencukur (menggundul) kepala si bayi dan melumurinya dengan minyak wangi (Daud, tt: 107).

Dari 'Aisyah, ia berkata, "Dahulu orang-orang pada masa jahiliyah apabila mereka ber'aqiqah untuk seorang bayi, mereka melumuri kapas dengan darah 'aqiqah, lalu ketika mencukur rambut si bayi mereka melumurkan pada kepalanya". Maka Nabi SAW. bersabda, "Gantilah darah itu dengan minyak wangi".

Demikianlah sejarah syariat 'aqiqah dalam Islam, dan dari riwayatriwayat diatas serta riwayat-riwayat lain, tampak jelas bagaimana sikap agama tercinta ini dalam menghadapi adat yang sudah biasa berjalan dan berlaku pada masyarakat dan masih mungkin diluruskan.

Tegasnya, Islam sesuai dengan fungsi diturunkannya yaitu sebagai lambang kasih sayang serta memimpin ke arah jalan yang serba positif, maka dalam menghadapi adat istiadat yang sudah biasa dilaksanakan sekelompok manusia, menempuh tiga macam cara yaitu: (1) Menghapusnya sama sekali, bila didalam adat-istiadat itu mengandung unsur-unsur kemusyrikan yang tidak mungkin diluruskan lagi, maupun hal-hal yang membahayakan keselamatan manusia itu sendiri; baik dari segi aqidah (rohani) maupun bagi tata masyarakatnya. Dalam hal ini Islam tidak dapat mentolerir atau membiarkannya hidup dan bersemi dalam kehidupan umatnya, karena sesuai dengan kenyataan, bahwa petani yang pandai serta bertanggungjawab terhadap berhasil dan suburnya sang padi, tidak akan membiarkan hidup alang-alang dan rumput-rumput liar yang ada di sekeliling padinya; (2) Sedang bila dalam adat-istiadat tersebut mengandung hal-hal yang bertentangan dengan agama akan tetapi masih dapat diluruskan, maka Islam datang untuk meluruskannya dan kemudian berjalan bersama-sama dengan Islam, sebagaimana masalah 'aqiqah ini; dan (3) Adapun adat-istiadat yang tidak mengandung unsur-unsur kemusyrikan dan kezhaliman serta tidak bertentangan dengan agama, maka Islam memelihara dan memberi hak hidup baginya untuk berkembang lebih lanjut dalam masyarakat tersebut tanpa sesuatu perubahan pun.

\section{Pemahaman Hadis Menurut Ulama Fiqh \\ Hukum Aqiqah}

Para ulama berselisih pendapat tentang hukum dari aqiqah: (a) Mazhab Hanafi, mereka menyebutkan bahwa hukum melaksanakan aqiqah adalah mubah bukan sunnat (Az-Zuhaili, tt: 636); (b) Mazhab Syafi'i, Abu Tsaur dan Jumhur, mereka menyebutkan bahwa hukum melaksanakan aqiqah adalah Sunnah Mu'akkadah; (c) Imam 
Malik berkata: "Aqiqah adalah suatu sunnah yang sangat dituntut untuk mengerjakannya; dan (d) Al-Laits dari Mesir dan Imam Daud Az-Zahiri, mereka mengatakan bahwa aqiqah wajib dilakukan pada hari yang ketujuh dari hari lahir si bayi. Jika tidak dikerjakan pada hari itu, tidaklah dikerjakan lagi pada tujuh yang kedua, tujuh yang ketiga, dan seterusnya.

\section{Jumlah Kambing Yang Disembelih.}

Menurut Mazhab Maliki, jumlah kambing yang disembelih yaitu Satu ekor kambing untuk anak laki-laki dan satu ekor kambing untuk anak perempuan. Berdasarkan hadits riwayat Ibnu Abbas:

$$
\text { عق عن الحسن شاة، وعن الحسين شاة }
$$

Artinya: "Rasulullah Saw mengaqiqahkan Hasan satu ekor kambing dan Husain satu ekor kambing".

Sedangkan menurut Mazhab Syafi'i dan Hanbali adalah dua ekor kambing untuk anak laki-laki dan satu ekor kambing untuk anak perempuan, berdasarkan hadits riwayat Aisyah:

$$
\text { عن الغلام شاتتان مكافئتان، وعن الجارية شاة }
$$

Artinya: "Untuk anak laki-laki dua ekor kambing yang sama dan untuk satu orang anak perempuan satu ekor kambing".

Berdasarkan dua hadits tersebut, jika disembelihkan satu ekor kambing untuk anak laki-laki, maka hukumnya sah. Jika disembelihkan dua ekor untuk anak laki-laki, maka afdhal. Karena hadits riwayat Ibnu Abbas mengandung makna boleh.

\section{Waktu Penyembelihan.}

Penyembelihan Aqiqah itu pada hari ke-tujuh setelah melahirkan, jika memungkinkan. Jika tidak, maka pada hari ke-14. Jika tidak memungkinkan, maka pada hari ke-21 sejak kelahirannya. Jika tidak memungkinkan, maka kapan saja pada hari-hari berikutnya. Dalam hadits riwayat alBaihaqi disebutkan: "Disembelihkan pada hari ke-7, ke-14 dan ke-21".

وصرح الثافعية والحنابلة: أنه لو ذبح قبل السابع أو أو

بعده، أجز أه

Mazhab Syafi'i dan Hanbali menyatakan: jika disembelihkan Aqiqah sebelum hari ketujuh atau setelah hari ketujuh, maka tetap sah (Az-Zuhaili, tt: 638).

\section{Pemahaman Hadis Menurut Ulama Hadits}

Ulama Hadits berbeda pendapat mengenai hadits ini, Ahmad bin Hanbal menyebutkan bahwa hadits ini berkaitan dengan syafa'at. Jika seorang anak lahir dan meninggal saat ia masih kecil, maka ia tidak dapat memberikan syafaat (pertolongan) untuk orang tuanya (Abadi, 1968: 37). Berbeda dengan pendapat Ibnul Qayyim, ia menegaskan, bahwa aqiqah itu berfungsi untuk melepaskan bayi yang bersangkutan dari godaan syaitan (Qayyim, 1994: 48-49).

Mengenai waktu penyembelihan, dalam kitab syarah 'aunul ma'bud dijelaskan bahwa tuzbahu 'anhu yauma sabi'ihi, maksudnya adalah waktu aqiqah itu adalah pada hari ke tujuh, tidak disyari'atkan sebelumnya dan tidak pula sesudahnya. Akan tetapi dibolehkan pada tujuh kedua (hari ke 14) dan tujuh ketiga (hari ke-21), sebagaimana disebutkan oleh al-Baihaqi dalam kitab Sunan al-Kubra: 


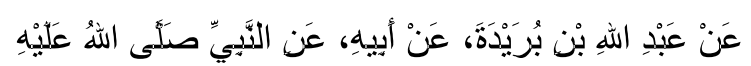

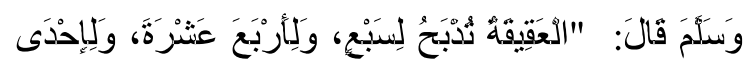

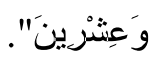

Artinya: "Dari Abdullah bin Buraidah dari ayahnya, dari Nabi Muhammad SAW. Ia bersabda: Aqiqah itu dapat disembelih pada hari ke tujuh, atau hari ke empat belas, atau hari ke dua puluh satu" (Abadi, 1968: 39).

\section{Nilai-Nilai Pendidikan Yang}

\section{Terkandung Dalam Matan Hadits}

Dalam kitab al-Fiqh al-Islamy wa Adillatuhu: disebutkan tentang hikmah Aqiqah adalah:

$$
\text { بـكر نعمة الله تعالى برزق الولد، وتنمية فضيلة الجود }
$$

Artinya: "Ungkapan syukur kepada Allah Swt atas diberi rezeki seorang anak. Menumbuhkan keutamaan berbagi dan sifat kedermawanan. Melembutkan hati keluarga, kerabat dan para sahabat dengan mengumpulkan mereka dengan makan bersama. Menebarkan kasih sayang, cinta kasih dan kebersamaan" (Az-Zuhaili, tt:285).

Dengan demikian, Aqiqah sama sekali bukan sekadar pesta makan. Praktiknya mungkin mengesankan begitu, tetapi esensinya jauh lebih luas daripada pengertian pesta makan. Sebagaimana dituturkan oleh DR. Abdullah Nashih Ulwan dalam buku tarbiyatul Aulad fi Al-Islam, hikmah aqiqah itu antara lain: (1) Aqiqah merupakan suatu pengorbanan yang akan mendekatkan anak pada Allah di masa awal ia menghirup udara; (2) Aqiqah merupakan tebusan bagi anak dari berbagai musibah, sebagaimana Allah telah menebus Ismail as dengan hewan sembelihan yang besar; (3)
Sebagai pembayaran hutang anak agar kelak di hari kiamat ia bisa memberi syafaat kepada kedua orang tuanya; (4) Merupakan media menunujukan rasa syukur atas keberhasilan melaksanakan syariat Islam dan bertambahnya generasi muslim; dan (5) Mempererat tali persaudaraan di antara sesama anggota masyarakat. Dalam hal aqiqah dapat menjadi semacam wahana bagi berlangsungnya komunikasi dan interaksi sosial yang sehat (Asrori, 1998: 99-100).

\section{SIMPULAN}

Dalam hadits terdapat nilai-nilai pendidikan yang terkandung dalam ibadah aqiqah, yaitu: (a) Penanaman Nilai-nilai Sosial (Pendidikan Sosial). Dengan disembelihkan hewan aqiqah sekaligus mengundang masyarakat sekitar untuk makan bersama, menunjukkan bahwa hal ini dilakukan untuk membangun kebersamaan dan persaudaraan dalam Islam. Juga terkandung pengajaran tentang kepedulian dan kepekaan sosial, berbagi dengan fakir miskin serta mengajarkan pentingnya Sillaturrahmi; (b) Nilai Kesehatan; (c) Dengan dicukurnya rambut pada hari ke tujuh, diharapkan ia tumbuh dengan rambutnya yang baru, karena selama dalam kandungan ibu bercampur dengan darah dan lain sebagainya, maka dihari diaqiqahkan itu juga dicukur rambutnya; (d) Penanaman Nilai Akhlak (Pendidikan Akhlak) seperti pengajaran tentang bersyukur atas nikmat yang Allah karuniakan, berdo'a bagian dari akhlak yang terpuji, penanaman nilai Keimanan (Pendidikan Keimanan), kegiatan membaca ayat suci al-Qur'an, menanamkan kecintaan kepada Nabi lewat shalawat, pemberian nama yang baik, karena nama adalah do'a, substansi Doa menyembelih aqiqah, penanaman nilai pengorbanan, 
mengaqiqahkan anak dengan mengorbankan harta, dan menyembelih hewan aqiqah tersebut seakan-akan menyembelih sifat-sifat kebinatangan yang ada pada anak.

\section{DAFTAR RUJUKAN}

Abadi, Abu at-Thayyib Muhammad Syams al-Haq al-'Azhim. 1968. 'Aunul Ma'bud, Jilid 8. Madinah alMunawwarah.

Al-Jauziyyah, Ibnul Qayyim. $1403 \mathrm{H}$. Tuhfatul-Maudud bi-AhkaamilMaulud, tahqiq : 'Abdul-Mun'im Al'Aaniy. Beirut: Daarul-Kutub Al'Ilmiyyah.

Al-Mizzi, Jamaludddin al-Hajjaj Yusuf. t.t. Tahzib al Kamal fi Asma' al Rijal, Juz 26. Beirut: Dar al Fikr.

Al-Nawawi, Abu Zakaria Muhyiddin bin Syaraf. t.t. Al-Majmu Syarh alMuhadzdzab li al-Syairazi, VIII. T.t.p.: Dar Ihya al- Turats al-Arabiy.
Asrori, Achmad Ma'ruf. 1998. Khitan dan Aqiqah. Surabaya: Al-Miftah.

Az-Zuhaili, Wahbah. t.t. Al-Fiqh al-islami wa adillatuhu. Jilid III. Beirut: Dar al-Fikr.

Daud, Abu. t.t. Sunan Abu Daud, Jilid 3. Beirut : Dar al-Fikr.

Manzur, Ibnu. t.t. Lisan al 'Arab, Kurnisy - an-Nil, Jilid IV. Kairo: Dar alMa'arif.

Qayyim, Ibnul. 14141H/1994 M. Tuhfatul Maudud bi Ahkamil Maulud, Tahqiq: Basyir Muhammad Uyun. Beirut: Darul Bayaan dan Maktabah al-Muayyad.

Usman, Abdurrahman Muh., 1979. 'Awn al-Ma'bud Syarh Sunan Abi Dawud. Mesir: al-Maktabah alSalafiyah.

Wensink, A.J., 1943. Mu'jam al-Mufahras li Alfazh al-Hadits al-Nabawiy, Jilid 2. Leiden: EJ. Brill.

Zakariya, Abu Husain Ahmad Ibnu Faris Ibn. t.t. Maqayis al- Lughah, Juz II. Beirut: Dar al-Fikr. 